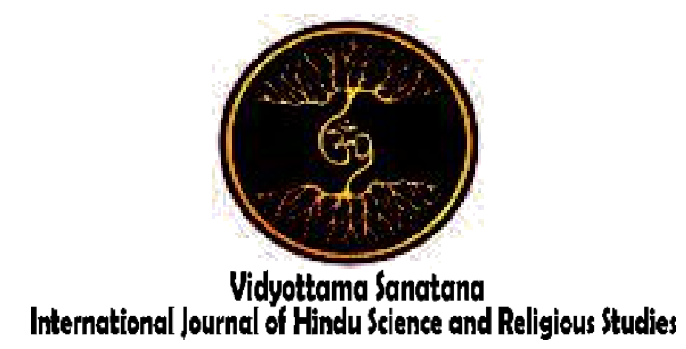

Vol. 2 No. 1 May 2018

\title{
Parenting Models In Building The Religious Characters Of Children
}

\author{
By: \\ Heny Perbowosari \\ Institut Hindu Dharma Negeri Denpasar \\ E-mail: henysari74@gmail.com
}

Received: January 11, 2018

Accepted: May 8, 2018

Published: May 31, 2018

\begin{abstract}
The religious character building is very important for the child and must be done starting from the family environment. The family has a responsibility in educating children, especially religious education. Religious education provided by parents will be the basis for children to behave in accordance with religious teachings. Parents play an important role in the child's religious character building, such as teaching obedience to religious teachings. A positive parenting style will have an impact on the formation of the child's religious character, especially the democratic style of parenting, in which the parent gives responsible freedom to the child. In the religious character building of children, the role of parents, are, provide exemplary, habituation, and dialogical communication with full warmth and affection.
\end{abstract}

\section{Keywords : Parenting Models, Religious Characters, Children}

\section{Introduction}

Parents have an important role in the process of growth and development of children. The role is not only from the physical aspect, but also the mental, social, character, and even personality. Parents not only have the obligation to have children, but also to care for their welfare, and to educate them to be human. Parents realize that children always need their attention and guidance.

Related to that, things that should be considered by parents in educating children, are as follows. First, the child's personal coaching. Every parent wants to nurture a child to be a good child, have a strong 
personality, a healthy mental attitude, and good morality. Parents are the first personal coaches in a child's life. Any experience the child goes through, either through sight, hearing or the treatment he receives will determine parents' personal coaching. Second, to understand the religious development of children is determined by the education and exercises done in childhood, because integrated education will foster religious development in an integrated manner as well. A child who, at the time of his childhood, has religious experiences such as his father and mother understand about religion, the social environment also practices religion. Therefore, the growth of religion in children depends on their parents. Third, exemplary attitude and good and positive actions carried out by parents is needed in educating children. Parents should set a good example and guide their children to the right path as expected.

In general, the family environment effects on the growth and development of children can be categorized into two, namely positive and negative effects. Positive effects are a living condition in which the growth and development of the child's personality are conducted naturally and optimally. Negative effects are a condition of family life that describes an atmosphere that is not conducive to the growth and development of children. Therefore, these conditions result in the child's developmental needs which are not met optimally and tend to deviate from most norms.

In the development of modern society, not all tasks and family functions must be done through the help of family. To provide education to children, they can be submitted to formal and nonformal education institutions. It is for the continuity of the task remains the responsibility of the family. Although some of the roles and functions of the family to the child can be partially handed over to others, the parents remain the first and foremost person for the child's life. Many experts link between family education and parenting that parents apply to educate their children. It is simply generally understood that parenting is basically the attitudes and habits of parents applied to nurturing, educating, and raising children at home. In providing education to children directed at the formation of character. Through parenting or education applied by parents, children will learn the behavior that parents show in order to meet their needs. In addition, the child will also be able to develop his desires and needs for a particular object or situation that has to do with the past.

The education that parents apply to their children is not the same because education and parenting are created and influenced by various factors, such as concepts, views, and values shared by parents, social background, education, work, and the child's own condition. In addition, because the characteristics of different families are influenced by their insights about the local cultural values, the parenting model is also different. There are patterns that tend to have an impact on positive behavior and there are also patterns that tend to negatively affect the development of a child's life. Parenting is closely related to the child's personality after he becomes an adult. This happens because the characteristics and elements of the character of an adult have actually put his seeds into the soul of an individual since very early, that is, in his childhood. The character is also determined 
by the ways he was taught small meals, cleanliness, discipline, play and hang out with other children, and so forth (Koentjaraningrat, 1997). Thus, it can be concluded that the parenting pattern applied by parents is very dominant in forming the child's personality from childhood until the child becomes an adult.

In parenting, there is also education, manners, forming responsibilities exercises, and so on. Here, the role of parents is very important because directly or not, parents through their actions will form the character of children and determine the attitude of children and their actions in the future.

Each parent, of course, has a separate parenting to direct the child's behavior. This is strongly influenced by the educational background of parents, living livelihood, socio-economic circumstances, customs, and so forth. In other words, the parenting of the farmer's parents is not the same as the trader. Similarly, the pattern of poorly educated parents is different than parenting of parents who are highly educated. Some apply a harsh, cruel, and callous pattern. However, some are applying a gentle pattern and affection. Others use military systems, ie, when their children are guilty, they will be given immediate punishment and firm action (authoritarian pattern). Various parenting applied by parents are very dependent on the forms of deviation behavior of children's learning. Parents can choose the right and ideal parenting for their children.

\section{Discussion}

\subsection{The Classification of Parents' Parenting}

The nurturing style consists of the various styles displayed by the parents at the time of parenting. Different parenting styles relate to the social development and personality of the child. Broadly speaking, parenting is reflected in two dimensions of parental behavior. The first dimension is the level and type of control that the parents exercise on the behavior of the child.

On the one hand, there are parents who are very hard to control and very demand to their children, on the other hand, there are also parents who never demanded to the child and rarely control them. The second dimension concerns on parents' involvement and their responsiveness to their children. On the one hand, some parents are very often involved with their children, both emotionally and in the provision of time and effort, while on the other hand, there are parents who are relatively uninvolved with their children and sometimes seem to reject their children.

Diana Baumrind (in Santrock, 2008) distinguished four kinds of parenting. First, authoritarian parenting which is limiting and punishing. Authoritarian parents urged children to follow their orders and respect them. They place strict limits and controls on their children and allow for little verbal communication. Children of authoritarian parents often behave in a less socially competent. They tend to worry about social comparisons, fail to start activities, and have poor communication skills. Second, authoritative parenting encourages children to be independent, but still places boundaries and controls their actions. Children who have authoritative parents tend to behave confidently, familiar with peers, and show high self-esteem. Third, neglectful parenting is that parents who are not involved in the lives of their children. Children of ignorant parents have poor self-control, lack good 
independence, and are not motivated to perform. Fourth, indulgent parenting is a parenting style with parental involvement, but there are few restrictions on children's behavior. The result of this parenting is to make the child cannot control the behavior, be too creative, and too confident.

In providing parenting or education to children, parents should become role models first, such as the opinion of $\mathrm{Ki}$ Hajar Dewantara who has a principle in providing education, namely Ing ngarso sung tulodho, ing madya mangun karsa, tutwuri handayani. That is, a teacher becomes an example, then, in the middle, the students build the initiative (will), and with the principle of tutwuri handayani, it will let them grow according to the age of growth, but still accompanied by educators.

Ki Hajar Dewantara (in Moh Shochib, 2000) stated that educational action is done with full conviction and aimed towards the safety and happiness of children. Every act of education is always based on the principles of momong, among, and ngemong. Educators are allowed to interfere with the child's life when he is on the wrong path, in order to grow according to his nature. When children do wrong, they are given punishment with the aim to awaken the child about his wrongdoing so as not to repeat again. Thus, educators are only given the authority to improve the child's behavior to grow properly and correctly. This is known as the amongst systems in which educators are tasked with developing the strength or potential that exists in each child.

In developing education based on $\mathrm{Ki}$ Hajar Dewantara's intermediate system (in Moh Shochib, 2000), it includes (1) modeling, (2) habituation, (3) teaching, (4) command, coercion and punishment, (5) behavior, and (6) inner or more often known experience with ngerti - ngrasa - nglakoni (understanding, realizing, doing).

Other forms of parenting directed to the formation of child behavior were proposed by Bowerman, Elder (in Conger, 1977). They present three kinds of parenting. The first authoritarian parenting is the parenting in which the parents make all decisions related to the child. The characteristics of authoritarian parenting, are rigid, firm, punitive, lack of affection and sympathetic, parents force children to obey the rules set, tends to curb the wishes of children, do not provide opportunities for children to be independent, praise, the right of the child is restricted, but is held accountable, tends to give physical punishment, do not give the child the right to express their opinion, holds the highest authority, requires the child to obey the parent's instructions, the parents are very powerful against their children. Second, democratic parenting is characterized in that all decisions which are made on the basis of agreement between the child and the parents. Third, permissive parenting, the character is the child has more influence than his parents in making decisions.

Lafore (in John W. Santrock, 2008) suggests that three kinds of parenting, namely (1) authoritarian parenting that has the characteristic feature of the power of parents, a less warm relationship between children and parents; (2) democratic parenting characterizes the relationship and cooperation between children and parents, the friendly attitude of the parents, the existence of a recognized child and the existence of mutual openness, 3). Permissive parenting pattern that has the characteristics of parents less 
functioning in controlling the attitude of children, and the power and the will of children who seem dominant.

Similarly, as argued by Argyle (in Dantes, 1992) that the pattern of parental approaches and interactions with children in the management of family education can be classified into three, namely authoritarian parenting, permissive parenting, and democratic parenting. Authoritarian parenting are characterized by parents in interactions with children, ie firm, punitive, unsympathetic. Parents force children to obey their values to try to form their children's behavior according to their own patterns of behavior and tend to curb the wishes of independent children. Children who are in an authoritarian family atmosphere then the activity is always determined and arranged by parents, so that children feel depressed. This will cause the child to be less initiative, hesitant, rebellious to the elderly, and obedient.

Permissive parenting are characterized by parental behaviors that give children as much freedom as possible. The child is not held accountable, the child is given freedom of self-regulation, and the parents do not much manage and control, maybe they do not even care about their children. Democratic parenting is characterized by the rights and obligations of parents and children alike in the sense that they are complementary. Parents train children to have a responsible attitude so that children can direct his behavior to achieve maturity.

Joan Gottman and Jean De Claire (2001) identify four typologies of parents in addressing the expressions of their child's emotions and their effects. First, ignorant parents are parents who ignore and disregard or underestimate child's negative emotions. Consequently, the child assumes that feelings are wrong, incorrect, or invalid. They may feel there is something wrong with their feelings and may also have difficulty managing their own emotions. Second, disagreeing parents are parents who are critical of their children's negative feelings. Third, parents who are laizees are parents who receive the emotions of their children and empathize but do not provide guidance or define the boundaries of their child's behavior. As a result, children do not learn to manage their emotions, face difficulty concentrating, and find it difficult to make friends or get along with others. Fourth, the parent who acts as an emotional coach is a parent who values the negative emotions of the child as an opportunity to become more familiar, empathize with the emotions that the child experiences. However, they guide and define the boundaries of their children's behavior. As a result, children learn to trust their feelings, regulate their own emotions, and solve problems. They also have high selfesteem and get along with others well.

Parenting contributes little in the personal formation of the child as every parent wishes. Idrus (2012) distinguishes three kinds of parenting of Javanese parents, namely as follows.

1. An encouraging parenting, with the following characteristics.

a. Deflecting unwanted goals, ie, Javanese parents guide their children by distracting the child from things that the parent thinks are not worth watching or inappropriate for children to see. 
b. Delaying the need for a moment, the parents of Java often delay the fulfillment of the needs of the child's wishes that according to parents has not been fulfilled.

c. Teach obedience, that is, Javanese parents have begun to introduce the values that their children have been obeying since the baby.

d. Teaches modesty, that is, the Javanese parents teach their children to be polite, both to parents, to elders, and to others since their child is a baby even though the child has not fully understood the behavior and words of those around him. One of the courtesy customs taught by Javanese parents is to teach their children from infancy to receiving or holding something with just the right hand.

e. Provide detailed, non-emotional commands, ie Javanese parents provide detailed, unemotional, and non-threatening commands. Although the command is given in detail, it is not based on emotion or threat of punishment if the commands are not done by the child.

f. Giving gifts, it is used as a Javanese parent strategy to familiarize themselves with behaviors expected by them and those around them.

2. Inhibiting parenting, with the following characteristics.

a. Scare children, that is, Javanese parents frighten their children through threats of terrible fate in the hands of others or spirits. However, this frightening model of parenting is driven by the desire of parents to have their children behave well. In addition, others will do evil to him if he does not show good attitude and behavior.

b. Providing punishment, that is, in this punishment, the Javanese parents rarely give a punishment that will eliminate the affection. This punishment will be given when a child has made a mistake or does not obey the order repeatedly and actually has angered the parents. Parents will not punish the first time a child makes a mistake, but wait until a new opportunity comes right to give him a punishment. The punishment given by the Javanese parents is not always a physical punishment or another verbal expression, but by having no talk or being called disatru.

c. Hostile, ie, its literal meaning is scolded or hostile usually with no talk.

3. Letting parenting, with the following characteristics.

a. Indulgence, ie let or liberate or not restrict children to play with peers.

b. Ngelulu, that is to let a child or someone do something he wants, but with the intention of giving awareness that this is actually not desired by the person who gives permission. 
Thus, parenting is a complex issue. However, it should be done as well as possible because the parents are the ones who are given the task by God to give birth, raise, guide, nurture, and educate the child.

\subsection{The Role of Parents in Forming the Religious Character of their Children}

Parents play a very important and very influential role in the education of their children. Since a child is born the mother is always there beside him, so he imitates his mother and his father, a child loves his mother more, let her do her job well. Mother is the first person known to the child, who first believed, anything that is done by the mother can be forgiven, except when he is left by understanding everything that sometimes in the heart of his child, also if the child has started to be an adult, accompanied by affection, can take child's heart forever.

The responsibilities that burden the parents at least should be implemented in order to:

1. Maintain and raise children, this is the simplest form of responsibility for every parent and is a natural incentive to sustain human survival.

2. Protect and guarantee the commonality, both physical and spiritual, from various diseases and from the misuse of life from the purpose of life in accordance with the philosophy of life.

3. Giving instruction in a broad sense, so that children have the opportunity to have the knowledge and skills as wide and as high as possible.

4. Happy children, both in the world and the hereafter, according to the views and purpose of life (Arthur, 2005).
In parenting, there are several attempts made in helping children who need to be preceded by the appearance of the following things. First, exemplary behavior. That is, every behavior is not just a mechanical behavior, but based on the awareness of its behavior will be used as a land of impersonation and identification of children.

Second, self-awareness is also transmitted to their children by encouraging them to adhere to their daily behavior of moral values. Therefore, parents always help them to be able to observe themselves through dialogical communication, which will bridge the gap of desire and purpose between parents and children.

Third, the dialogical communication that occurs between parents and their children, especially those relating to efforts to help them to solve problems related to moral values. In this case, the parents are able to control the behavior of their children so that they can increase moral values as a basis for self-disciplined behavior. Through such control, it means that parents have supervised and guided their children to behave in accordance with moral values.

Fourth, organizing the social environment by the way parents are required to create a pattern of intercultural relationships, how to communicate, cohesiveness, and the existence of educational indications that contain moral values. This communication pattern can make family members familiar, intimate, belonging to each other, and feel safe in the family. Familiarity, intimacy, belonging and feeling secure in the family can cultivate children's emotions well. 
In an effort to educate children to be good, it can be done several things, they are, as follows. First, mom and dad must be compact to choose the parenting that will be applied to the child. Do not be wise and fickle so the child does not get confused. Second, to be a parent who deserves to imitate children by modeling positive things in everyday life. Do not let the child be forced to do good things that his parents do not want to do. Children will respect and appreciate their parents so that adults will love the parents and other family members. Third, adjust the pattern of care with the situation, conditions, abilities, and needs of children. Foster pattern of children under five would be different from the pattern of foster teenagers. Do not educate children at a cost that their parents can not afford. Keep your child easy to understand what we want without feeling the compulsion, but on the basis of self-awareness. Fourth, discipline remains preferred in guiding children from childhood to adulthood so that children can be independent and respected and appreciated by the community. Small things, such as getting up on time, helping with the homework of parents, studying diligently is one form of discipline and responsibility for children. Fifth put forward and cultivate early on religion and good morality in the child so that in the future can be a pious person and have good and religious attitude and behavior. A righteous child will always pray for the parents who have given birth and raised him even though his parents have passed away. Sixth, communication is done openly and fun with certain limitations so that children are used to the opening to the parents when there is something to be conveyed or things that interfere with his mind. If angry parents should use a good and indirect expression that can be understood children so that children do not necessarily become closed and consider parents unpleasant. Seventh, avoid negative actions in children, such as scolding children for no reason, sending children as casually as unlimited helpers, dropping children mentally, smoking, lazy worship, fooling children, lying to children often, bringing home stress from the office, feeding on money forbidden to children, reluctant to take care of children, too busy with work, and so forth.

Parents do not only have the obligation to get children, but also care for the welfare of children, and educate them to be human. In taking care of the child from the time of preparing for the birth of the child, the parents enter into a state of concern which, according to Koentjaraningrat in Mulder (1983: 37) is translated as "a heightened awareness of disturbing events". Both parents, especially mothers, should eat less, take taboos, and hold a slametan to guarantee a favorable birth. In addition to performing rituals, the obligation of parents is to keep their children to be people (dadi wong) which means to be an honorable member of the community.

To be an honorable person, the Javanese usually instilled some things, among others, to instill awareness to know the rules of Javanese culture. If they have not done the rule, it is said that the children durung Java. That is, not yet a Javanese. In addition, also instilled a sense of isin (shame). This sense can contribute to the development of respect for others and the desire to avoid conflict.

Parents, especially fathers become the object of reverence (talisman pepundhen) which means respected and glorified due to 
the advisory provided. Because under good moral guidance the child can develop himself into a virtuous person.

In the Javanese family environment, parents must educate their children to be good people. In the expression of Javanese language can mendhem jero lan mikul dhuwur, it means covering the hole deep and high bearing. This phrase implies that mendhem jero means children must cover the shortcomings, ugliness, and mistakes of parents. Thus, children always praise the goodness of parents, while mikul dhuwur is a child must keep the good name of parents with good behavior.

\subsection{The Strategy of Cultivating Religious Values in Children}

In forming the character of a good child, it is necessary to care and the role of parents to instill in children the sense of the importance of doing good, following the rules. It is packaged in the form of religious values in children. The cultivation of religious values should be started from an early age, where this period is said to be a golden age, the duty of parents to guide and counsel the child so that children can develop optimally and become the next generation of quality.

The cultivation of religious values is the basis for the personality of the child, therefore the need for a strategy or method. As in Nashih Ulwan (1990) pointed out that in inculcating the value of religious values required influent methods (influential) to children, they are: (1) exemplary: where the child's behavior starts from imitating parent skills, for example: teaches honesty, (3) counseling: the parent seeks to counsel the child according to the stage of his age to a time when he is able to counsel himself and others, (4) supervision: where the children need to be watched and supervised so that they are in the right direction and do not behave deviate from the rules, so that one can reach spiritual maturity, (5) the giving of the law: this is done as the last step, and in giving punishment should be within certain limits, so as not to harm and hurt children and not result in trauma to children.

In addition to instill religious values that should be done by parents, are: (1) provide reward and punishment, which approaches appreciation and prohibition which are done when children do good and positive things should be rewarded, vice versa if the child made a mistake should be given reasonable punishment. As in Azzet (2010) the purpose of this strategy is to establish honest behavior in children and children will be more disciplined in carrying out religious activities, (2) Habituation is done to form children to accustomed to performing the habit of carrying out religious activities such as praying before and after doing activities, pray daily. This habituation will evoke the motivation of children to do positive things and applied every day, (3) exemplary: to change the behavior of children, then parents need to provide examples, implement and apply activities, not just tell the child to pray, get up early, wash hands before eating but parents should practice and invite children to do it, (4) create a religious atmosphere at home: parents always invite children to make religious at home like invite every morning before school to pray together, children get used to saying "Om Swastyastu" when meeting with anyone, so this will become a habit in everyday life. 


\section{Conclusion}

Parenting models in the care of children depend on the insights and characteristics of each family. There are patterns that tend to have an impact on positive behavior and there are patterns that tend to negatively affect the development of a child's life. Parenting is closely related to the child's personality after he becomes an adult. To make a good character in children, including religious characters, the parents' role is required. In this case, the parents should give examples of religious behavior, make a dialogical dialogue between parents and children. This is done by parents by way of providing guidance and supervision of their children. This communication pattern can make family members familiar, intimate, belonging to each other, and feel safe in the family. Familiarity, intimacy, belonging together, and feeling secure in the family can foster religious character in children. In addition, it requires a strategy such as providing reward and punishment in children, doing habituation such as praying, giving exemplary in children, as well as creating a religious atmosphere at home.

\section{References}

Abdullah Nashih Ulwan. 1990. Pendidikan Anak Dalam Islam. Jakarta : Pustaka Amani.

Ary Ginanjar Agustian. 2001. ESQ Emotional Spiritual Quotient The ESQ Way 165. Jakarta : PT Arga Tilanta.

Augusto Cury. 2007. Brilliant Parent Fascinating Teachers. Jakarta : PT. Gramedia Pustaka Utama.

Azzet, Akhmad Muhaimin. 2010. Mengembangkan Kecerdasan Spiritual Bagi Anak. Yogyakarta : Katahati.
Bhandesa, A. M., Suyasa, I. G. P. D., \& Darmapatni, N. W. K. (2017). The Educational Value of Hinduism on the Gumi Suda Ceremony at the Birth of the Twin Babies with Different Genders (Case Study at Pakraman Village of Ketewel, Sukawati District, Gianyar Regency). Vidyottama Sanatana: International Journal of Hindu Science and Religious Studies, 1(2), 93-102.

Dantes. 1992. Pola Asuh Dalam Hubungannya Dengan Pendidikan Nilai di Lingkungan Keluarga : Suatu Analisis Makropedagogik. Pidato Pengukuhan Jabatan Guru Besar Singaraja Universitas Udayana.

Idrus. 2012. Pendidikan Karakter Pada Keluarga Jawa. Jurnal Pendidikan Karakter Vol. II (2) : 118 - 130.

Arthur, John Mac. 2005. Kiat Sukses Mendidik Anak Dalam Tuhan. Jakarta : Penerbit Immanuel

Niels Mulder. 1996. Pribadi dan Masyarakat di Jawa. Jakarta : Penerbit Sinar Harapan.

Koentjaraningrat. 1982. Kebudayaan, Mentalitas dan Pembangunan, Jakarta : Gramedia.

Santrock, John.W. 2002. Life Span Development : Perkembangan Masa Hidup, (terje.) Acmad Chusairi. Jakarta : Erlangga.

Santrock, John.W .2009. Psikologi Pendidikan (Educational Psychology) Terjemahan. Jakarta : Penerbit Salemba Humanika.

Shochib. Moh, 2000. Pola Asuh Orang Tua Untuk Membantu Anak Mengembangkan Disiplin Diri. Jakarta : PT. Rineka Cipta. 